\title{
Does the symmetry of the breasts continue after breast augmentation?
}

\author{
Meme simetrisi protez implantasyonu sonrasında devam eder mi? \\ Nazım Gümüş, Sarper Yılmaz
}

Plastic, Reconstructive and Aesthetic Surgery Department (Assist. Prof. N. Gümüş, MD, Prof. S. Y1lmaz, MD), Cumhuriyet University School of Medicine, TR-58140 Sivas

\begin{abstract}
Aim. Augmentation mammaplasty is one of the most common aesthetic surgical interventions, which proves excellent results that pretend high rate of patient satisfaction. In this study, our main aim was to investigate whether breast symmetry might carry on after augmentation or not. Methods. The study included 21 patients who had hypomastia with or without grade 1 ptosis. Each patient was assesed for ptosis, asymmetry of the nipples, inframammary fold position, base constriction, breast mound, and finally chest wall before and after the operation. Asymmetry between the breasts preoperatively was accepted as a cause for exclusion from the study. All of the patients who had symmetric breasts underwent augmentation mammaplasty using gel filled breast implants, in which implantation, intraareolar incision and prepectoral subglandular placement method was chosen. Results. Breasts were evaluated by four independent surgeons preoperatively and in the postoperative period by means of ptosis, asymmetry of the nipple-areola, inframammary fold position, base constriction, breast mound, skin wrinkling, double-bubble apperance, rippling and softness. Less visible areolar scar took place on incision site without depigmentation. In most of the patients, good breast shape was provided by the augmentation, which satisfied them. While the breasts were symmetric in two patients preoperatively, severe difference between the shape of the breasts was realized by the patients and surgeons one year after the augmentation. Conclusion. We think that when breasts are augmented, some of differences, even if they are too less to be noticed, increases considerably. So, previously insignificant discrepansies related with volume, areolar size and inframammary fold may become clear after the operation. It seems that submuscular or subfacial placement of prosthesis may provide avoidance but further comparative studies with longer follow-up period are needed for a conclusion.
\end{abstract}

Keywords: Asymmetry, augmentation, subglandular placement, breast shape, intraareolar incision

Özet

Amaç. Büyütme mammoplastisi estetik cerrahi uygulamaların en sık olarak yapılanlarından birisidir. Mükemmel sonuçlar sağlayarak yüksek hasta memnuniyetine yolaçar. Bu çalışmada, meme simetrisinin büyütme mammoplastisi sonrasında devam edip etmediğinin araştırılması amaçlandı. Yöntemler. Çalışma, evre 1 pitozu olan veya olmayan 21 hipomastili hastayı içerdi. Her bir hastada meme pitozu, meme başı asimetrisi, meme altı kıvrım pozisyonu, taban yapısı, meme tümseği ve göğüs duvarı yapısı ameliyat öncesi ve sonrasında değerlendirildi. Ameliyat öncesi asimetri bulgusu olan hastalar çalışmadan çıkarıldı. Tüm simetrik memeli olgularda intraareolar kesi ve pektoral kas önü-gland altı yöntem kullanılarak jel dolu meme protezi ile büyütme mammoplastisi yapıldı. Bulgular. Operasyon öncesi ve sonrası dönemde memeler dört bağımsız cerrah ve hastalar tarafından değerlendirildi. Meme pitozu, meme başı asimetrisi, meme altı kıvrım pozisyonu, taban yapısı, meme tümseği, cilt kıvrılması, meme başlarının yukarı bakması ve meme yumuşaklığı kontrol edildi. Depigmentasyon olmaksızın az belirgin areolar kesi izi oluştu. Hastaların çoğunda hedeflenen ve hastaları memnun eden güzel meme şekli, büyütme mammoplastisi ile elde edildi. İki olguda ameliyat öncesinde meme simetrisi olmasına rağmen, operasyondan bir yil sonra hem hastalar hemde cerrahlar tarafindan fark edilen ciddi asimetri gelişti. Sonuç. Meme büyütme operasyonu sonrasında simetri değerlendirildiğinde, meme büyütmesi ile birlikte memeler arasındaki farklılıkların, hatta operasyon öncesi fark edilemeyecek kadar küçük olanların bile arttığı görülmüştür; böylece hacim, areola boyutu ve meme altı kıvrımdaki belirgin olmayan farklılıklar görünür hale gelmektedir. Kas veya fasiya altı protez yerleştirme bu durumdan kaçınmayı sağlayabilir, ancak uzun süreli kıyaslamalı çalışmalara ihtiyaç vardir.

Anahtar sözcükler: Asimetri, büyütme, gland altı yerleştirme, meme şekli, areola içi kesi 
Geliş tarihi/Received: December 01, 2011; Kabul tarihi/Accepted: June 14, 2012

*Corresponding author:

Dr Nazım Gümüş, Plastik, Rekonstrüktif ve Estetik Cerrahi Anabilim Dalı, Cumhuriyet Üniversitesi Tıp Fakültesi, TR-58140 Sivas. E-Mail: gumus1970@hotmail.com

\section{Introduction}

Augmentation mammaplasty is one of the most common aesthetic surgical interventions. It proves excellent results, causing high rate of patient satisfaction. Preoperative anatomical evaluation of the patients is important in planing of the surgery, which gives detailed information about the operation and its results forming the patients' expectations related to cosmetic outcomes. Possible complications involving early and late breast shape, incision site, selected surgical procedure and implant should be discussed with patients. Anatomical features of the chest and breasts and preexisting asymmetries of the chest wall, nipple-areola complex and breast mound should be examined preoperatively because they considerably influence the final aesthetic results of the breast augmentation. All information and signs about the breasts are shared completely with the patients to avoid developing serious problems between the surgeons and the patients after the augmentation. Generally, complications of augmentation mammaplasty and breast shape after the operation are well known, but sometimes there is a possibility of undesirable surprises as in the following study, including severe asymmetry one year after the augmentation.

\section{Materials and methods}

This study included 21 patients who had hypomastia with or without grade 1 pitosis. Their ages varied from 23 to 42 years with an avarage age of 27 years. Patients had been evaluated carefully by four independent physicians using physical examination and standardized preoperative photographs before they were admitted for the study. Each patient was assessed for ptosis, asymmetry of the nipples, inframammary fold position, base constriction, breast mound, and finally chest wall. Asymmetry between the breasts was accepted as a cause for exclusion preoperatively (figure 1a, b and c, 2a, b and c). Some patients who had minimal differences between the breasts according to the assessment of the surgeons, were included into the study, if the patients accepted theirselves as symmetrical.

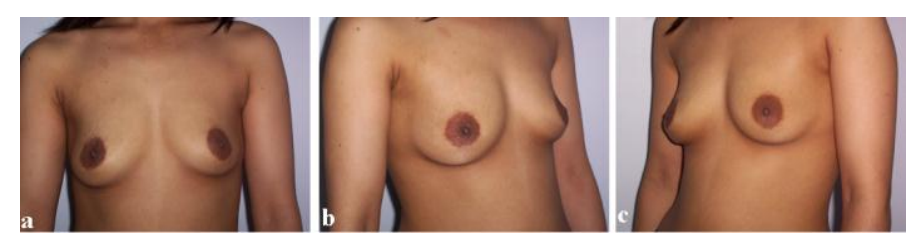

Figure 1.a. Preoperative view of 26 years old women who had hypomastia. Symmetry was completely observed. b. Preoperative view of the same patient viewing on the right. c. Preoperative view of the same patient viewing on the left.
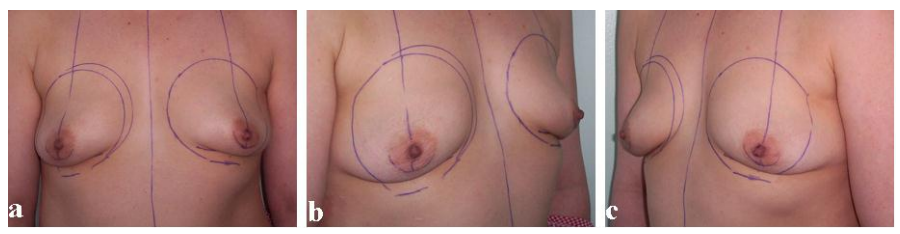

Figure 2.a. View of the 35 years old patient, whose hypomastia treated with using 300 cc breast implant. According to the preoperative findings, these breasts were symmetric. $b$. View of the breasts from other side. c. View of the patients from another side. 
All of the patients who had symmetric breasts underwent augmentation mammaplasty with using gel filled breast implants, for which intraareolar incision and prepectoral subglandular placement of the implants were chosen to perform. Subglandular dissection was continued $2 \mathrm{~cm}$ below to the submammarian fold. As breasts were symmetric in preoperative evaluation, the same implant which was identic to the other regarding size, shape and texture, was placed to other breast to protect symmetry. In the follow-up period, each patient was examined every 12 months after the operation, during 3 years.

\section{Results}

None of the cases developed heamatoma, seroma, infection or wound dehiscens. Breasts were evaluated by the surgeons and the patients for ptosis, asymmetry of the nippleareola, inframammary fold position, base constriction, breast mound, skin wrinkling, double-bubble apperance, rippling and softness every 12 months after the augmentation. Less visible areolar scar took place on incision sites without depigmentation. In most of the patients, good breast shape was created by the augmentation, which satisfied them. Capsular contracture was occured in one case 24 months after the operation. Although, in two patients breasts were symmetric in preoperatively, one year after the augmentation, considerable differences between breasts were realized by the patients and the surgeons. Discrepancies of the areolar diameter, breast projection, inframammary fold position, breast volume, and implant ptosis were the reasons for asymmetry of the breasts which were augmented by the same implant and the same surgical approach (figure $1 \mathrm{~d}, \mathrm{e}, \mathrm{g}, \mathrm{h}$ and i). Nipple sensation temporarly changed in four patients during the early postoperative period; however, it turned to normal in a few months and permenant loss of sensation did not occur in the follow-up examinations.

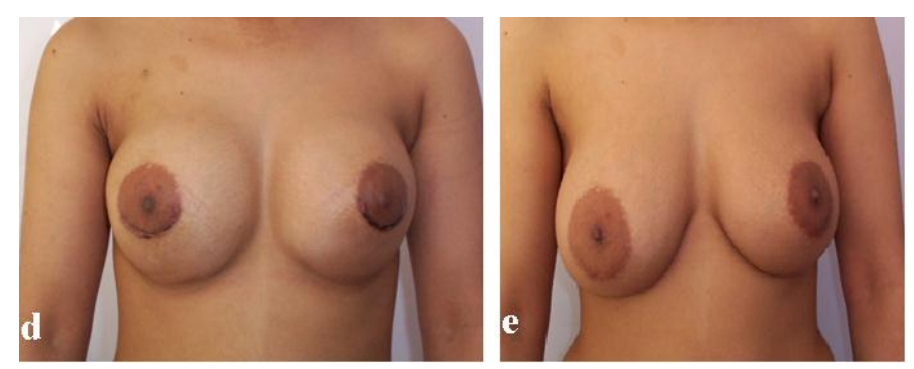

Figure 1.d. Apperance of the breasts, 3 weeks after augmentation with using 300 cc gel filled texured implant. Note that submammarian fold, breast volume and areolar size were similar in both breasts. e. Breast apperance, one year after the subglandular augmentation. Significant asymmetry occurred.
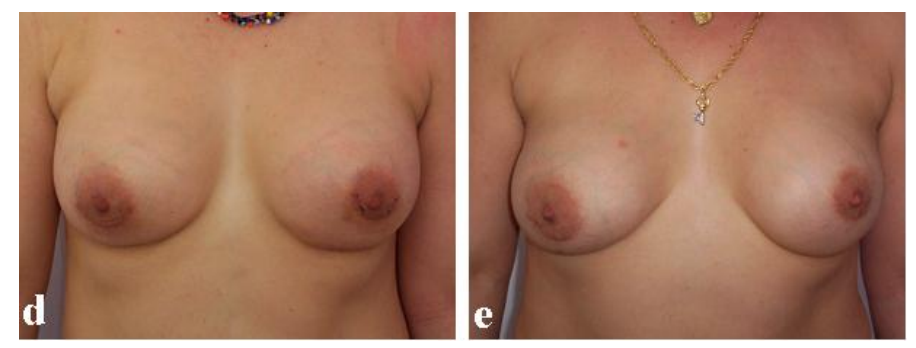

Figure $2 \mathrm{~d}$. Apperance of the breasts, three weeks after the surgery. At first, we made more upper pole fullness than the lower pole, because some of implant pitosis would take place after the operation. e. One year after the augmentation, apperance of the breastss. Note the differences between the breasts for volume, areolar size and projection. 


\section{Discussion}

Aesthetic outcomes of the augmentation mammaplasty have been showed clearly in every surgical techniques. Each incision site, implant placement area or features of implant have some advantages and disadvantages, so selection of the surgical approach should be made according to each patient's individual characteristics to obtain best results. Most occuring complications after the breast augmentation including hematoma, infection, seroma, capsular contracture, malposition and rupture of the implant, rippling, ptosis and asymmetry have been reported in detail [1-3]. In some surgical techniques, occurrence rates of the complications have been claimed to be more common than the another approaches. Capsular contracture seems to occur more frequently in the subglandular placement than in the submuscular placement [4, 5]. As periareolar incision for augmentation is recommended for patients who have more than $3.5 \mathrm{~cm}$ areolar diameter, in patients with smaller size of the areola another surgical options should be chosen [6]. Possible side effects of this incision are altered nipple sensation, impaired lactation, an increased rate of infections with capsular fibrosis and well visible scar formation with hypopigmentation [6]. Of our patients who had suitable areolar diameter for incision, one developed capsular contracture. Transient change of nipple sensation occurred in 4 patients in the early postoperative period. It has been reported that two years after breast augmentation, $89 \%$ of women who underwent breast augmentation with intraareolar incision judged their breast sensation to be normal, but objective assessment showed that mean pressure and vibration sensation were moderately compromised in all parts of the breast [6]. We could avoid this complication with using different dissection technique for insertion of implant. After the intraareolar skin incision, a tunnel was created with dissection of breast tissue from skin, between areola and submammarian fold, so prepectoral dissection was began just over the fold. Thus, implant placement was made into the subglandular pocket at nearly lowest margin of the breast. Our aesthetic results regarding breast mound, areola nipple position and upper pole fullness were good and all patients were satisfied. In a corresponding study, it has been emphasized that in the presence of grade II ptosis, periareolar approach results in improved fill of the lower pole of the breast, improved centralization of the nipple on the breast mound, and lessening or elimination of undesirable upper pole fullness [7]. Breast asymmetry after augmentation may be caused by preexisting breast or thoracic asymmetry, implant rotation or malposition, loss of implant integrity, and capsular contractures. Additionally, in early postoperative period seroma and heamatoma may be a factor for asymmetric breast apperance. Especially, in cases where anatomical implant is used, malposition, rotation or displacement, either upwards or downwards, cause significant asymmetry due to the implant shape. This may take place more frequently with using anatomical implant than round shape. Also, initial malposition and/or erroneous incision are thought to be the main causes of displacement or implant rotation, which may develop after the augmentation [8]. Preexisting breast or thoracic asymmetry has been emphasized to be the most important predictable cause for postoperative asymetry. In a study which included 100 patients who underwent bilateral augmentation, when each patient was examined for ptosis, asymmetry of the nipples, breast mound and chest wall preoperatively, significant asymmetries in all parameters were found. Moreover, overall 88 percent of the women had some degree of asymmetry, and 65 percent of the women had more than one parameter of asymmetry. Authors recommended that a systematic preoperative breast and chest wall analysis should be individualized for each patient [9]. As our patients did not have significant preexisting breast or thoracic asymmetry, we did not expect any asymmetry postoperatively. But, in this study our main aim was to learn whether breast symmetry might go on after augmentation or not. A little dicrepansies between the breasts' shapes might be accepted as normal, but severe asymmetry was surprising. As initial evaluation of the patients regarding the presence of thoracic or breast asymmetry revealed normal findings, the same implant could be inserted in the operations, but asymmetric breast apperance was observed in two patients one year after 
the intervention. It is well known in the literature that breast shape changing after augmentation continues along years, but the effect of augmentation on breast symmetry is obscure. A main factor affecting breast shape is the chosen surgical technique; therefore, in these cases subglandular placement of the implants may be the major cause. It has been proposed that, by placing the prosthesis behind the pectoral muscle interposition of additional soft tissue between the implant may occur and the observer may disguise the otherwise apparent problem, thus making its correction more apparent than real [10].

We think that when breasts are augmented, some of the differences, even if they are too less to be noticed, increase with time, so previously insignificant discrepansies related to volume, areolar diameter and inframammary fold may become evident after the operation. Another cause of asymmetry may be different resistances of breast tissues against prosthesis. Whatever explanation we make, it may be emphasized that an investigation for the breast shape in the mobile population is very difficult, but, afer the augmentation, severe breast asymmetry may occur and augmentation does not protect previous breast symmetry in some cases. It seems that submuscular or subfacial placement of prosthesis may provide to avoid from it, but long term corresponding studies are required.

\section{References}

1. Brown MH, Shenker R, Silver SA. Cohesive silicone gel breast implants in aesthetic and reconstructive breast surgery. Plast Reconstr Surg 2005; 116: 76879.

2. Henriksen TF, Hölmich LR, Fryzek JP, Friis S, McLaughlin JK, Høyer AP, Kjøller K, Olsen JH. Incidence and severity of short-term complications after breast augmentation: results from a nationwide breast implant registry. Ann Plast Surg 2003; 51: 531-9.

3. Hidalgo DA. Breast augmentation: choosing the optimal incision, implant, and pocket plane. Plast Reconstr Surg 2000; 105: 2202-16.

4. Gylbert L, Asplund O, Jurell G, Olenius M. Results of subglandular breast augmentation using a new classification method--18-year follow-up. Scand J Plast Reconstr Surg Hand Surg 1989; 23: 133-6.

5. Fiala TG, Lee WP, May JW Jr. Augmentation mammoplasty: results of a patient survey. Ann Plast Surg 1993; 30: 503-9.

6. Kompatscher P, Schuler C, Beer GM. The transareolar incision for breast augmentation revisited. Aesthetic Plast Surg 2004; 28: 70-4.

7. Importance of the periareolar approach in the augmentation of the ptotic breast. Ann Plast Surg 2002; 48: 460-2.

8. The non-perfect results of breast implants. Ann Chir Plast Esthet 2005; 50: 53443.

9. Rohrich RJ, Hartley W, Brown S. Incidence of breast and chest wall asymmetry in breast augmentation: a retrospective analysis of 100 patients. Plast Reconstr Surg 2003; 111: 1513-9.

10. Biggs TM, Yarish RS. Augmentation mammaplasty: retropectoral versus retromammary implantation. Clin Plast Surg 1988; 15: 549-55. 